\title{
Tanzania Graduate Employability: Perception of Human Resource Management Practitioners
}

\author{
Kelvin M Mwita \\ Assistant Lecturer, Mzumbe University \\ School of Public Administration and Management (SOPAM) \\ P. O Box 2, Mzumbe, Tanzania
}

Received: April 1, 2018 Accepted: April 25, 2018 Online published: May 6, 2018

doi:10.5296/ijhrs.v8i2.12921ＵRL: https://doi.org/10.5296/ijhrs.v8i2.12921

\begin{abstract}
Higher Education Institutions (HEI's) produce many qualified graduates in different fields of study annually but almost half of them become frustrated or desolate because they cannot secure jobs in the labour market and some have huge student loans to settle. Moreover, Tanzania education stakeholders have been arguing that the education offered is not adequately geared to integrate the individual into the strong competitive labour markets. The study used a sample of 100 human resource practitioners to assess their perception of Tanzania graduate employability. It was found that HR practitioners consider Tanzania graduate as average. It has been found that $52.6 \%$ of Human Resource practitioners disagree that Tanzania graduate quality is improving. Additionally $56.6 \%$ believe that Tanzania graduate are not competent enough to compete for jobs in the East African labour market. The study recommends various measures to be taken by higher learning institutions, regulatory bodies, policy makers and students themselves.
\end{abstract}

Keywords: graduate employability, Tanzania, labour market, human resource management, recruitment

\section{Introduction}

The concept and definition of employability has been discussed for a number of years but there has been a growing interest in graduate employability over the last decade (Lowden, Hall, Elliot, \& Lewin, 2011). Employability means a - set of skills, knowledge and personal attributes that makes an individual more likely to secure and be successful in their chosen occupation(s) to the benefit of themselves, the workforce, the community and the economy.' (Yorke, 2006). Kinash et al, (2014) insist that employability is not restricted to securing employment. It also encompasses longevity, success and lifelong learning during one's career. 
The extent, to which university education is capable of producing potential employable graduates in the competitive $21^{\text {st }}$ century world, is attracting the attention of scholars and policymakers globally (Pitan, 2017). One of the functions of university is to provide people with knowledge and skills that are relevant to the labour market (Santiago et al., 2008). This implies that once graduates from universities do not meet labour market demands various stakeholders have to question the quality of education provided by these institutions. Higher Education Institutions (HEI's) produce many qualified graduates in different fields of study annually but almost half of them become frustrated or desolate because they cannot secure jobs in the labour market and some have huge student loans to settle (Paadi, 2014).

There is a concern worldwide that the current undergraduate curriculum is not producing graduates with the kind of professional and lifelong learning skills that they require to be successful in their jobs. This shortcoming has put increasing pressure on universities to enhance the employability of graduates by ensuring that university learning experiences translate into a fulfilling transition to the labour market (Pitan, 2017). A study done by British Council (2014) in Sub-saran Africa reported that there is widespread concern about the work readiness of graduates. While employers are generally satisfied with the disciplinary knowledge of students, they perceive significant gaps in their IT skills, personal qualities (e.g. reliability) and transferable skills (e.g. team working and problem solving).

Tanzania education stakeholders have been arguing that the education offered is not adequately geared to integrate the individual into the strong competitive local and international labour markets (Mbise, 2014). A number of studies have been done in Tanzania that seeks to assess graduate employability from various perspectives and contexts. This study aimed at examining HR practitioners' perception of Tanzania graduates.

\section{Literature Review}

At the beginning of the 1960s human capital theory constituted the primary social science narrative of relations between higher education and work (Marginson, 2015). A core thesis of human capital theory is that education renders people more productive, that is, it raises the marginal product of an educated worker relative to the one not so educated (Merwe, 2010). Generally speaking, the theory argues that education system or generally education transforms people by making them more useful for value creation and addition and hence makes them more employable. Paadi (2014) opines that the theory does not lean much towards the acquisition of generic skills to succeed in the workplace since it focuses more on the educational knowledge acquired through higher education to be successful in work which is not sufficient to make a person competent enough for a job. The study by British Council (2014) which was done in four Sub-Saharan countries (Ghana, Nigeria, Kenya and South Africa) to represent the region found evidence that employers are not satisfied with the level of skills and qualities of graduates. The study further noted that one of the greatest challenges facing Sub-Saharan Africa is one of robust research and evidence on which to base policy formulation. There is a severe lack of research - particularly as regards the effectiveness of policy reforms or local-level interventions. This calls for more research to be done in the area so that policy makers will have statistical base in decision making as far improving quality of 
education is concerned. Prisca (2016) conducted a study seeking to examine the perceptions and experiences of education-job mismatch among humanities graduates in Cameroon and how the mismatch affected them. The study found that education-job mismatch was attributed to the weak and stagnating economy which stifled job creation, excess supply of graduates in the labour market, outdated curriculum and the disconnect between the universities and the labour market. The findings also revealed that being mismatched resulted to poor and irregular income, job dissatisfaction, lack of a dignified social status and career identity, and the inability to make long term plans. Being in mismatched jobs also resulted to feelings of unaccomplished expectations, disappointment, frustration and distress for the graduates and all these had multiplier effects on the health of the graduates.

Global Graduate Employability Research by Kinash et al, (2014) which collected data from a total of 14 countries including the United Republic of Tanzania identified 7 themes or attributes that distinguish a top-performing graduate. These themes include; skills (both work-specific (hard) and transferable (soft)); real-world experience (through engaging with industry and employers throughout university, and staying informed about current events and global issues, graduates have developed outward looking perspectives, appreciation for context and realistic notions and expectations of the workforce); well-rounded perspectives in addition to study, successful graduates had pursued sports and/or hobbies as well as community engagement. Other themes are value alignment (employees are a good fit with the organisation, sharing values such as a customer service orientation); social support (employees are resilient and able to handle work-related stress when they have healthy family relationships and friendships); initiative (motivation and enthusiasm are important in that employees are then able to self-initiate tasks and find intrinsic reward in work); and Goal-oriented to learning (employees make the most of opportunities to develop and do not have unrealistic expectations of immediate high-level positions).

\section{Methods and Characteristics of the Sample}

A sample of $120 \mathrm{HR}$ practitioners from both public and private organisations operating in Tanzania was conveniently selected through an online survey. A structured questionnaire was administered online whereby respondents using various digital devices were able to fill in the questionnaire. Data were collected from November, 2017 to February, 2018. Out of 120, a total of $100 \mathrm{HR}$ practitioners responded to the questionnaires which made $83.3 \%$ response rate. Thirty five (35) respondents were females and sixty five (65) were males. Respondents were also categorised basing on nature of the organisations they are working for; 47 were from private organisations while 53 from public organisations. Age of the respondents are summarised in the Table 1 below;

Table 1. Demographic Data

\begin{tabular}{lll}
\hline Age group & Number of Respondents & Percentage \\
\hline $18-24$ & 2 & $2 \%$ \\
$25-34$ & 56 & $56 \%$ \\
$35-44$ & 39 & $39 \%$ \\
$45-54$ & 2 & $2 \%$ \\
$55-64$ & 1 & $1 \%$ \\
Total & $\mathbf{1 0 0}$ & $\mathbf{1 0 0}$ \\
\hline
\end{tabular}


Source: Researcher's own computation from questionnaires

\section{Findings and Discussion}

\subsection{HR Practitioners Perception on Personal Qualities of Tanzania Graduates}

Human resource practitioners were asked to rate Tanzania graduates using five point Likert scale ranging from very poor (1), below average (2), average (3), above average (4) to excellent (5). Ten (10) personal qualities were evaluated and the responses are summarised in the Table 2 below

Table 2. Perception of Personal Qualities

\begin{tabular}{|c|c|c|c|c|c|c|}
\hline & Very Poor & \begin{tabular}{|l} 
Below \\
Average \\
\end{tabular} & Average & \begin{tabular}{|l|} 
Above \\
Average
\end{tabular} & Excellent & $\begin{array}{l}\text { WEIGHTED } \\
\text { AVERAGE }\end{array}$ \\
\hline Adaptability & $\begin{array}{l}2 \\
(2.02 \%)\end{array}$ & $\begin{array}{r}13 \\
(13.13 \%)\end{array}$ & $\begin{array}{r}59 \\
(59.60 \%)\end{array}$ & $\begin{array}{r}20 \\
(20.20 \%)\end{array}$ & $\begin{array}{r}5 \\
(5.05 \%)\end{array}$ & 3.13 \\
\hline $\begin{array}{l}\text { Attention to } \\
\text { Detail }\end{array}$ & $\begin{array}{r}5 \\
(5.10 \%)\end{array}$ & $\begin{array}{r}22 \\
(22.45 \%)\end{array}$ & $\begin{array}{r}55 \\
(56.12 \%)\end{array}$ & $\begin{array}{r}14 \\
(14.29 \%)\end{array}$ & $\begin{array}{r}2 \\
(2.04 \%)\end{array}$ & 2.86 \\
\hline Commitment & $\begin{array}{r}4 \\
(4.30 \%)\end{array}$ & $\begin{array}{r}28 \\
(30.11 \%)\end{array}$ & $\begin{array}{r}45 \\
(48.39 \%)\end{array}$ & $\begin{array}{r}15 \\
(16.13 \%)\end{array}$ & $\begin{array}{r}1 \\
(1.08 \%)\end{array}$ & 2.80 \\
\hline Integrity & $\begin{array}{r}10 \\
(10.20 \%)\end{array}$ & $\begin{array}{r}25 \\
(25.51 \%)\end{array}$ & $\begin{array}{r}48 \\
(48.98 \%)\end{array}$ & $\begin{array}{r}14 \\
(14.29 \%)\end{array}$ & $\begin{array}{r}1 \\
(1.02 \%)\end{array}$ & 2.70 \\
\hline Initiative & $\begin{array}{r}14 \\
(14.74 \%)\end{array}$ & $\begin{array}{r}32 \\
(33.68 \%)\end{array}$ & $\begin{array}{r}39 \\
(41.05 \%)\end{array}$ & $\begin{array}{r}8 \\
(8.42 \%)\end{array}$ & $\begin{array}{r}2 \\
(2.11 \%)\end{array}$ & 2.49 \\
\hline Self-awareness & $\begin{array}{r}7 \\
(7.22 \%)\end{array}$ & $\begin{array}{r}35 \\
(36.08 \%)\end{array}$ & $\begin{array}{r}35 \\
(36.08 \%)\end{array}$ & $\begin{array}{r}15 \\
(15.46 \%)\end{array}$ & $\begin{array}{r}5 \\
(5.15 \%)\end{array}$ & 2.75 \\
\hline $\begin{array}{l}\text { Punctuality/time } \\
\text { keeping }\end{array}$ & $\begin{array}{r}14 \\
(14.29 \%)\end{array}$ & $\begin{array}{r}30 \\
(30.61 \%)\end{array}$ & $\begin{array}{r}35 \\
(35.71 \%)\end{array}$ & $\begin{array}{r}14 \\
(14.29 \%)\end{array}$ & $\begin{array}{r}5 \\
95.10 \% 0\end{array}$ & 2.65 \\
\hline $\begin{array}{l}\text { Tolerance to } \\
\text { stress }\end{array}$ & $\begin{array}{r}15 \\
(15.31 \%)\end{array}$ & $\begin{array}{r}35 \\
(35.71 \%)\end{array}$ & $\begin{array}{r}30 \\
(30.61 \%)\end{array}$ & $\begin{array}{r}12 \\
(12.24 \%)\end{array}$ & $\begin{array}{r}6 \\
(6.12 \%)\end{array}$ & 2.58 \\
\hline Work ethic & $\begin{array}{r}12 \\
(12.24 \%)\end{array}$ & $\begin{array}{r}28 \\
(28.57 \%)\end{array}$ & $\begin{array}{r}42 \\
(42.86 \%)\end{array}$ & $\begin{array}{r}14 \\
(14.29 \%)\end{array}$ & $\begin{array}{r}2 \\
(2.04 \%)\end{array}$ & 2.65 \\
\hline Cooperation & $\begin{array}{r}5 \\
(5.15 \%)\end{array}$ & $\begin{array}{r}13 \\
(13.40 \%)\end{array}$ & $\begin{array}{r}53 \\
(54.64 \%)\end{array}$ & $\begin{array}{r}20 \\
(20.62 \%)\end{array}$ & $\begin{array}{r}6 \\
(6.19 \%)\end{array}$ & 3.09 \\
\hline
\end{tabular}

Source: Researcher's own computation from questionnaires

In Table 2 above the highest mean score is 3.13 in the area of adaptability which is generally an average one while the lowest mean score is 2.49 in the area of initiative which also falls under the category of average.

Personal qualities are generally perceived by human resource practitioners to be 2.77 which is an average score. It can simply be concluded that human resource practitioners consider personal qualities of Tanzania graduates to be average. This is alarming because many organisations through a recruitment process aim to ensure that they choose the best available 
candidates, often using additional tools such as assessment centres, presentations and psychometric tests to better evaluate the applicants (Fáilte Ireland, 2013). This entails that if employers cannot find right candidates in the country the other option is looking for them in other countries. As noted by Mubanga (2014) overtime there has been growing complaints from the general public on employment of foreigners. This is probably attributed to the perception of employers that local graduates are just average ones hence they do not meet the required qualities as per labour market demands.

\subsection{Core Skills of Tanzania Graduates}

In core skills 10 skills were used to assess Tanzania graduates and the results are tabulated below;

Table 3. HR Practitioners Perception on Core Skills

\begin{tabular}{|c|c|c|c|c|c|c|}
\hline & Very Poor & \begin{tabular}{|l} 
Below \\
Average
\end{tabular} & Average & \begin{tabular}{|l|} 
Above \\
Average
\end{tabular} & Excellent & $\begin{array}{l}\text { WEIGHTED } \\
\text { AVERAGE }\end{array}$ \\
\hline $\begin{array}{l}\text { Oral } \\
\text { Communication }\end{array}$ & $\begin{array}{r}6 \\
(6.12 \%)\end{array}$ & $\begin{array}{r}27 \\
(27.55 \%)\end{array}$ & $\begin{array}{r}44 \\
(44.90 \%)\end{array}$ & $\begin{array}{r}19 \\
(19.39 \%)\end{array}$ & $\begin{array}{r}2 \\
(2.04 \%)\end{array}$ & 2.84 \\
\hline $\begin{array}{l}\text { Written } \\
\text { Communication }\end{array}$ & $\begin{array}{r}7 \\
(7.07 \%)\end{array}$ & $\begin{array}{r}19 \\
(19.19 \%)\end{array}$ & $\begin{array}{r}38 \\
(38.38 \%)\end{array}$ & $\begin{array}{r}28 \\
(28.28 \%)\end{array}$ & $\begin{array}{r}7 \\
(7.07 \%)\end{array}$ & 3.09 \\
\hline $\begin{array}{l}\text { Commercial } \\
\text { awareness }\end{array}$ & $\begin{array}{r}12 \\
(12.24 \%)\end{array}$ & $\begin{array}{r}32 \\
(32.65 \%)\end{array}$ & $\begin{array}{r}40 \\
(40.82 \%)\end{array}$ & $\begin{array}{r}14 \\
(14.29 \%)\end{array}$ & $\begin{array}{r}0 \\
(0.00 \%)\end{array}$ & 2.57 \\
\hline Ethical issues & $\begin{array}{r}5 \\
(5.05 \%)\end{array}$ & $\begin{array}{r}33 \\
(33.33 \%)\end{array}$ & $\begin{array}{r}48 \\
(48.48 \%)\end{array}$ & $\begin{array}{r}12 \\
(12.12 \%)\end{array}$ & $\begin{array}{r}1 \\
(1.01 \%)\end{array}$ & 2.71 \\
\hline IT & $\begin{array}{r}14 \\
(14.29 \%)\end{array}$ & $\begin{array}{r}31 \\
(31.63 \%)\end{array}$ & $\begin{array}{r}36 \\
(36.73 \%)\end{array}$ & $\begin{array}{r}13 \\
(13.27 \%)\end{array}$ & $\begin{array}{r}4 \\
(4.08 \%)\end{array}$ & 2.61 \\
\hline Leadership & $\begin{array}{r}10 \\
(10.31 \%)\end{array}$ & $\begin{array}{r}38 \\
(39.18 \%)\end{array}$ & $\begin{array}{r}35 \\
(36.08 \%)\end{array}$ & $\begin{array}{r}12 \\
(12.37 \%)\end{array}$ & $\begin{array}{r}2 \\
(2.06 \%)\end{array}$ & 2.57 \\
\hline Negotiation & $\begin{array}{r}18 \\
(18.56 \%)\end{array}$ & $\begin{array}{r}32 \\
(32.99 \%)\end{array}$ & $\begin{array}{r}32 \\
(32.99 \%)\end{array}$ & $\begin{array}{r}12 \\
(12.37 \%)\end{array}$ & $\begin{array}{r}3 \\
(3.09 \%)\end{array}$ & 2.48 \\
\hline Numeracy & $\begin{array}{r}15 \\
(15.79 \%)\end{array}$ & $\begin{array}{r}25 \\
(26.32 \%)\end{array}$ & $\begin{array}{r}46 \\
(48.42 \%)\end{array}$ & $\begin{array}{r}7 \\
(7.37 \%)\end{array}$ & $\begin{array}{r}2 \\
(2.11 \%)\end{array}$ & 2.54 \\
\hline $\begin{array}{l}\text { Problem } \\
\text { solving }\end{array}$ & $\begin{array}{r}10 \\
(10.31 \%)\end{array}$ & $\begin{array}{r}31 \\
(31.96 \%)\end{array}$ & $\begin{array}{r}38 \\
(39.18 \%)\end{array}$ & $\begin{array}{r}14 \\
(14.43 \%)\end{array}$ & $\begin{array}{r}4 \\
(4.12 \%)\end{array}$ & 2.70 \\
\hline Team-working & $\begin{array}{r}7 \\
(7.29 \%)\end{array}$ & $\begin{array}{r}19 \\
(19.79 \%)\end{array}$ & $\begin{array}{r}46 \\
(47.92 \%)\end{array}$ & $\begin{array}{r}20 \\
(20.83 \%)\end{array}$ & $\begin{array}{r}4 \\
(4.17 \%)\end{array}$ & 2.95 \\
\hline
\end{tabular}

Source: Researcher's own computation from questionnaires

Comparatively in this category, Tanzania graduates have highest score in written communication by a score of 3.09 while the lowest score is 2.57 in both leadership and commercial knowledge. Yet all these scores are not promising since they fall under an average score. The weighted score of all the core skills is 2.7 which is also an average one. Since the core skills are very crucial in performance of any job, employability challenge of 


\section{Ml Macrothink}

International Journal of Human Resource Studies

ISSN 2162-3058

2018, Vol. 8, No. 2

Tanzania graduates may be attributed to this fact. Suneela (2014) opined that employers recruit outstanding, motivated individuals; people with enthusiasm; have the courage to lead, have values, skills, strong analytical and conceptual abilities and individuals passionate about learning. With this regard average graduates always find difficult to secure jobs in a competitive labour market.

\subsection{HR Practitioners' Perception on Subject Knowledge of Tanzania Graduates}

In subject knowledge four criteria were used to assess Tanzania graduates, these are understanding of concepts, breadth of knowledge, application of knowledge, and up-to-date. Understanding of the concepts was rated 3.02, breadth of knowledge 2.82, application of knowledge 2.75 and possession of up-to-date knowledge 2.71 .

Table 4. Subject Knowledge of Tanzania Graduate

\begin{tabular}{|c|c|c|c|c|c|c|}
\hline & Very Poor & \begin{tabular}{|l} 
Below \\
Average
\end{tabular} & Average & Above Average & Excellent & $\begin{array}{l}\text { WEIGHTED } \\
\text { AVERAGE }\end{array}$ \\
\hline $\begin{array}{l}\text { Understanding } \\
\text { concepts }\end{array}$ & $\begin{array}{r}7 \\
(7.14 \%)\end{array}$ & $\begin{array}{r}19 \\
(19.39 \%)\end{array}$ & $\begin{array}{r}41 \\
(41.84 \%)\end{array}$ & $\begin{array}{r}27 \\
(27.55 \%)\end{array}$ & $\begin{array}{r}4 \\
(4.08 \%)\end{array}$ & 3.02 \\
\hline $\begin{array}{l}\text { Breadth of } \\
\text { knowledge }\end{array}$ & $\begin{array}{r}8 \\
(8.16 \%)\end{array}$ & $\begin{array}{r}22 \\
(22.45 \%)\end{array}$ & $\begin{array}{r}50 \\
(51.02 \%)\end{array}$ & $\begin{array}{r}16 \\
(16.33 \%)\end{array}$ & $\begin{array}{r}2 \\
(2.04 \%)\end{array}$ & 2.82 \\
\hline $\begin{array}{l}\text { Application of } \\
\text { knowledge }\end{array}$ & $\begin{array}{r}10 \\
(10.31 \%)\end{array}$ & $\begin{array}{r}23 \\
(23.71 \%)\end{array}$ & $\begin{array}{r}46 \\
(47.42 \%)\end{array}$ & $\begin{array}{r}17 \\
(17.53 \%)\end{array}$ & $\begin{array}{r}1 \\
(1.03 \%)\end{array}$ & 2.75 \\
\hline Up-to-date & $\begin{array}{r}12 \\
(12.24 \%)\end{array}$ & $\begin{array}{r}27 \\
(27.55 \%)\end{array}$ & $\begin{array}{r}39 \\
(39.80 \%)\end{array}$ & $\begin{array}{r}17 \\
(17.35 \%)\end{array}$ & $\begin{array}{r}3 \\
(3.06 \%)\end{array}$ & 2.71 \\
\hline
\end{tabular}

Source: Researcher's own computation from questionnaires

The weighted average for all four criteria is 2.83 which is also an average score. From this point of view yet Tanzania graduates do not have sufficient knowledge on their subject knowledge which may raise a number of questions on the quality of Tanzania education system and motivation of students to search for knowledge from various sources. While on this area the highest score (3.02) is on understanding concepts the lowest score (2.71) is on possession of up-to-date information which portrays that students and graduates are not working hard in looking for current up-to-date information in their fields of study. It is essential to recognise that employers judge graduates on the basis of how successfully they have completed their degree course (i.e. their degree classification) perhaps because this is often the sole measure available to them (Pool \& Sewell, 2007). This means that knowledge on a specific field is important in making a graduate employable.

\subsection{Trend of Tanzanian Graduates Quality}

Respondents were asked to say their level of agreement or disagreement on the statement "as time goes by quality of Tanzania graduates is improving". Out of 93 respondents who answered this question $51(52.6 \%)$ disagreed while 46 respondents $(47.4 \%)$ agreed. One of 
probable reasons as to why the quality of Tanzania graduates is considered deteriorating by human resource practitioners is the increase of number of higher learning institutions which do not offer education that meets expected standards. This also reflects the feedback from employers who complain about the quality of Tanzania fresh graduates. As noted by Istoroyekti (2016) private companies complain on the inability of the fresh graduates to perform duties properly in workplace. Besides, best score shown in the academic transcript does not guarantee job performance. Academic performance is not accompanied by soft skill salient to workplace. This also raises questions on criteria used to assess students in higher learning institutions and if what is taught in these institutions is compatible with what the labour market demands. Paadi (2014) reminds that a graduate can be very intelligent and actually pass their degree with distinctions but if they do not display a fair amount of the necessary soft or generic skills they can jeopardise their chances of employability.

\subsection{Position of Tanzania Graduates in the East African Labour Market}

The East African community has opened doors for free movement of labour across the member states. Due to geographical proximity between member states people can move to one country and secure jobs in the other country. With this regard respective countries are supposed to make sure that their education systems provide graduates that are capable of competing for jobs in the labour market.

Human resource practitioners were asked to tell whether they think Tanzania graduates are competent enough to compete for jobs in the labour market. Out of 99 who responded to this question, $58(56.6 \%)$ think that Tanzania graduates are not competent enough while 43 respondents (43.4\%) believed that they are. According to the findings by the Inter-University Council for East Africa (IUCEA) which regulates higher education in the East African Community's five countries reported that $61 \%$ of graduates from Tanzania higher learning institutions are unfit for jobs (Nganga, 2014)

\section{Conclusion and Recommendations}

Generally, Tanzania graduates are considered average by Human Resource practitioners in Tanzania with weighted average score of 2.8 out of 5 . It can be concluded that Tanzania graduates do not meet the required demands of the labour market. Human resource practitioners are also concerned about the quality of graduates from higher learning institutions. For organisations to attain competitive advantage, hiring employees with the best qualities is unavoidable. Having graduates who are considered average may trigger unemployment in the country since they will be unwanted by employers but also it may lead to preference of foreign employees to local employees.

It is recommended that higher learning institutions should conduct labour market research to understand well the labour market demands that can be used as a base in developing their curriculums. Higher learning institutions should also develop special programmes aiming at equipping students with soft skills which they seem to lack.

Tanzania Commission for Universities (TCU) and National Council for Technical Education (NACTE) have to ensure that higher learning institutions adhere to global standards in the 
provision of education and training services. Policy makers have to develop effective education policies through an open participatory process that will involve all important stakeholders. Students in higher learning have to take personal initiatives that aim at improving their employability skills, this includes, but not limited to attending workshops and seminars, mentorship programmes, and volunteering to gain more experience

\section{References}

British Council. (2014). Can Higher Education Solve Africa's Job Crisis? Understanding Graduate Employability in Sub-Saharan Africa. British Council.

Fáilte, I. (2013). Recruitment and Selection: A Guide to Help You Review Your Existing Approach to Recruitment and Selection. Fáilte Ireland: Dublin.

Istoroyekti, Y. (2016). Issues Challenging Universities: A Case of Tanzanian Higher Education. Ahmad Dahlan Journal of English Studies, 3(1), 51-62. https://doi.org/10.26555/adjes.v3i1.3625

Kinash, S., Crane, L., Knight, C., Dowling, D., Mitchell, K., McLean, M., \& Schulz, M. (June, 2014). Global graduate employability research: A report to the Business20 Human Capital Taskforce (DRAFT). Gold Coast, QLD Australia: Bond University.

Lowden, K., Hall, S., Elliot, D., \& Lewin, J. (2011). Employers' Perceptions of the Employability Skills of New Graduates. Edge Foundation, London.

Marginson, S. (2015). Rethinking education, work and 'employability': Foundational problems of Human Capital Theory. Paper presented at SRHE conference, Newport, Wales, 9 December 2015.

Mbise, E. R. (2014). The employability of business schools' graduates in the labour market in Tanzania: An exploratory study. International Journal of Social Sciences and Entrepreneurship, 1(13), 562-576.

Merwer, A. (2010). Does Human Capital Theory Explain The Value Of Higher Education? A South African Case Study. American Journal of Business Education, 3(1), 107-118.

Mubanga, C. B. (2014). Locals versus Foreigners: The Simmering Discontent of Employment of Foreigners in Tanzania. A Dissertation Submitted in Partial Fulfillment of the Requirements for the Award of The Degree of Master of Laws the Open University of Tanzania.

Nganga, G. (2014). Survey finds most East African graduates 'half-baked'. http://www.universityworldnews.com/article.php?story=20140523130246934

Paadi, K. (2014). Perceptions on Employability Skills Necessary to Enhance Human Resource Management Graduates Prospects of Securing a Relevant Place in the Labour Market. European Scientific Journal. Special Edition, 129-143.

Pitan, O. S. (2017) Towards Enhancing University Graduate Employability in Nigeria. Journal of Sociology and Social Anthropology, 7(1), 1-11. 


\section{Macrothink \\ International Journal of Human Resource Studies \\ ISSN 2162-3058 2018, Vol. 8, No. 2}

https://doi.org/10.1080/09766634.2016.11885696

Pool, L. D., \& Sewell, P. (2007). The key to Employability: Developing a Practical Model of Graduate Employability. Emerald, 49(4), 277-289.

Prisca, N. (2016). Education-job mismatch among university graduates in Cameroon: The Perspectives of Graduates in the Field of Humanities. Master's thesis in Development Geography, Faculty of Social Sciences, University of Oslo.

Santiago, P., Tremblay, K., Basri, E., \& Arnal, E. (2008b) Tertiary Education for the Knowledge Society (vol. 1: Special features: Governance, Funding, Quality). Paris: OECD Publishing. https://doi.org/10.1787/9789264063518-hu

Suneela, E. R. (2014). Soft Skills are Employability Skills; With Special Reference to Communication Skills. Journal of Humanities and Social Science, 19(8), 59-61. https://doi.org/10.9790/0837-19845961

Yorke, M. (2006). Employability in higher education: what it is - what it is not. Learning and Employability Series 1. The Higher Education Academy: Heslington

\section{Appendix}

\section{Questionnaire}

My name is Kelvin Mwita, Assistant Lecturer at Mzumbe University I am doing an online survey on HR Practitioners' Perception of graduate employability in Tanzania. Kindly assist me by filling in this questionnaire. Note: This questionnaire is intended for HR Practitioners only; kindly do not fill in if you are not.

\section{Instruction(s)}

Please check the appropriate box in the questions below,

1. Nature of the organisation you are working with

(a) Public

(b) Private ( )

2. What is your Gender?

(a) Male

(b) Female ( )

3. What is your age?
(a) $18-24$
(b) 25-34
(c) $35-44$
(d) $45-54$ 
(e) $54-64$

(f) Above 64( )

4. In general, how do you rate the following Personal Qualities of Tanzania graduates?

\begin{tabular}{l|l|l|l|l|l}
\hline Item & Very Poor & $\begin{array}{l}\text { Below } \\
\text { Average }\end{array}$ & Average & $\begin{array}{l}\text { Above } \\
\text { Average }\end{array}$ & Excellent \\
\hline Adaptability to & & & & & \\
\hline $\begin{array}{l}\text { Attention } \\
\text { Detail }\end{array}$ & & & & & \\
\hline Commitment & & & & & \\
\hline Integrity & & & & & \\
\hline Initiative & & & & & \\
\hline Self-awareness & & & & & \\
\hline $\begin{array}{l}\text { Punctuality/time } \\
\text { keeping }\end{array}$ & & & & & \\
\hline $\begin{array}{l}\text { Tolerance to } \\
\text { stress }\end{array}$ & & & & & \\
\hline Work ethic & & & & & \\
\hline Cooperation & & & & & \\
\hline
\end{tabular}

5. In general, how do you rate the following Core Skills of Tanzania graduates

\begin{tabular}{l|l|l|l|l|l}
\hline Item & Very Poor & $\begin{array}{l}\text { Below } \\
\text { Average }\end{array}$ & Average & $\begin{array}{l}\text { Above } \\
\text { Average }\end{array}$ & Excellent \\
\hline $\begin{array}{l}\text { Oral } \\
\text { Communication }\end{array}$ & & & & & \\
\hline $\begin{array}{l}\text { Written } \\
\text { Communication }\end{array}$ & & & & & \\
\hline $\begin{array}{l}\text { Commercial } \\
\text { awareness }\end{array}$ & & & & & \\
\hline Ethical issues & & & & & \\
\hline IT & & & & & \\
\hline Leadership & & & & & \\
\hline Negotiation & & & & & \\
\hline Numeracy & & & & & \\
\hline $\begin{array}{l}\text { Problem } \\
\text { solving }\end{array}$ & & & & & \\
\hline Team-working & & & & & \\
\hline
\end{tabular}

6. In general, how do you rate Subject Knowledge of Tanzania Graduates?

\begin{tabular}{l|l|l|l|l|l}
\hline Item & Very Poor & $\begin{array}{l}\text { Below } \\
\text { Average }\end{array}$ & Average & $\begin{array}{l}\text { Above } \\
\text { Average }\end{array}$ & Excellent \\
\hline $\begin{array}{l}\text { Understanding } \\
\text { concepts }\end{array}$ & & & & & \\
\hline $\begin{array}{l}\text { Breadth of } \\
\text { knowledge }\end{array}$ & & & & & \\
\hline $\begin{array}{l}\text { Application of } \\
\text { knowledge }\end{array}$ & & & & & \\
\hline Up-to-date & & & & & \\
\hline
\end{tabular}




\section{Macrothink \\ International Journal of Human Resource Studies \\ ISSN 2162-3058 2018, Vol. 8, No. 2}

7. As time goes by quality of Tanzania graduates is improving
(a) Strongly Agree
(b) Agree
(c) Disagree
(d) Strongly Disagree ( )

8. Tanzania graduates are competent enough to compete for jobs in the East African Labour Market
(a) Strongly Agree
(b) Agree
(c) Disagree
(d) Strongly Disagree ( )

\section{Copyright Disclaimer}

Copyright for this article is retained by the author(s), with first publication rights granted to the journal.

This is an open-access article distributed under the terms and conditions of the Creative Commons Attribution license (http://creativecommons.org/licenses/by/4.0/). 